Ann. Biol. anim. Bioch. Biophys., 1978, 18 (6), 1273-1278.

\title{
On the nature of monoamine oxidase control by thyroxin in the heart, brain and brown adipose tissue of the developing rat
}

par D. GRIPOIS

Laboratoire d'Endocrinologie, Université Paris-Sud, Bât. 490. 91405 Orsay, France.

Summary. The aim of the present work was to defermine whether the increase in monoamine oxidase activity previously found in hyper-and hypothyroid rats, was due to thyroxin effects on enzymatic activity or to variations in enzyme synthesis.

The rate of synthesis of monoamine oxidase in young hyper- and hypothyroid rats has been studied by measuring the recovery of enzymatic activity 7 days after irreversible inhibition by Pargyline. Hyperthyroidism was followed by an increase in the rate of synthesis of monoamine oxidase in the heart and a decrease in the brain. Hypothyroidism led to an increase in brown adipose tissue.

Thyroxin increased cardiac monoamine oxidase activity in vitro in the late fetal period, but not in the newborn or the adult.

The results show that thyroxin controls monoamine oxidase activity in the newborn rat primarily by acting on the rate of synthesis of the enzyme.

\section{Introduction.}

In the last 20 years, a number of reports have dealt with the effects of thyroid hormones on monoamine oxidase (MAO ; EC. 1-4-3-4) in different organs, especially in the heart. In the adult rat (Utley, 1964 ; Lyles and Callingham, 1974 ; Callingham and Lyles, 1974 ; Tong and d'lorio, 1976) as well as in the newborn (Novick, 1961 ; Gripois and Fernandez, 1976, 1977a) and the fetus (Gripois and Fernandez, 1977b), hyperthyroidism is followed by an increase in cardiac MAO activity, while hypothyroidism leads to a decrease.

It is not yet known, however, whether these changes are due to an altered rate of synthesis of the enzyme or to an effect on its activity. Tong and d'lorio (1976) failed to show the presence of an activator or inhibitor of MAO activity in the soluble fraction of liver and heart homogenates from normal or hyperthyroid adult rats; this result suggests that thyroxin has no direct effect on MAO activity. This conclusion is in agreement with the previous results of Asaad and Clarke (1975) who found that L-triiodothyronine has no in vitro effect on rat heart MAO. In other organs, it has also been shown that in vitro, thyroxin or triiodothyronine can activate rat brain MAO (Asaad and 
Clarke, 1975) but has no effect on liver enzyme (Okamato, 1971). On the other hand, triiodothyronine administration in vivo is followed by an accelerated rate of synthesis of the enzyme in rat salivary glands (Goridis and Neff, 1973).

Since this type of study yielded rather conflicting results in adult animals, we attempted to clarify the problem in the young rat, when thyroid control of MAO is greater than in the adult (Gripois and Fernandez, 1977a). Two types of experiments in the developing rat were undertaken : 1) the study of the influence of hyper-and hypothyroidism on MAO synthesis in the heart, brain and brown adipose tissue by determining the recovery of MAO activity after irreversible inhibition by Pargyline ; 2 ) the effect of thyroxin on cardiac MAO activity in vitro.

\section{Materials and methods.}

Studies in vivo. - Newborn male Sherman rats were divided into four experimental groups. «Control » animals received no treatment. «PTU » rats were rendered hypothyroid by administering propylthiouracil to their mothers (50 mg PTU per day in $3 \mathrm{ml}$ of water) by gastric intubation. " $\mathrm{NaOH}$ » animals received daily injections of the same volume of $0.009 \mathrm{M} \mathrm{NaOH}$ as the $\mathrm{T} 4$ animals $(0.01 \mathrm{ml}$ per $\mathrm{g}$ of body weight). "T4 » rats were rendered hyperthyroid by daily subcutaneous thyroxin injections (0.25 mg T4 Roche per $\mathrm{kg}$ of body weight) in $0.009 \mathrm{M} \mathrm{NaOH}$.

All treatments were begun on the day of birth (day 0 ) and were continued until the day of sacrifice (days 13 or 20). The size of the litters was kept between 8 and 10 young males. In order to measure the rate of synthesis of MAO, rats were intraperitoneally injected with Pargyline hydrochloride (Abbott) at a dose of $10 \mathrm{mg}$ per $\mathrm{kg}$ of body weight, in distilled water, on day 13. The animals were killed either $3 \mathrm{hrs}$ later (= day 13 ) or 7 days later (= day 20) and interscapular brown adipose tissue, heart

\section{TABLE 1}

Effects of PTU and thyroxin on MAO activity in the young rat. Rats were injected with pargyline $3 \mathrm{~h}$ before sampling at 13 days. For details, see materials and methods. MAO activity is expressed in cpm/20 min/100 $\mu \mathrm{g}$ of tissue \pm Standard Error ; ( ) : No. of cases

\begin{tabular}{|c|c|c|c|c|c|}
\hline & Age (days) & Controls & PTU & $\mathrm{NaOH}$ & $\mathrm{T}_{4}$ \\
\hline Brown adipose tissue ..... & $\begin{array}{l}13 \\
20\end{array}$ & $\begin{array}{c}291 \pm 72 \\
(8) \\
264 \pm 26 \\
(9)\end{array}$ & $\begin{array}{c}90 \pm 12 \\
(7) \\
241 \underset{(8)}{ \pm} 19\end{array}$ & $\begin{array}{c}147 \pm 18 \\
(7) \\
291 \underset{(9)}{ \pm} 9\end{array}$ & $\begin{array}{c}52 \pm 10 \\
(7) \\
203 \pm 21 \\
(9)\end{array}$ \\
\hline Heart & $\begin{array}{l}13 \\
20\end{array}$ & $\begin{array}{c}155 \pm 45 \\
(8) \\
364 \pm 26 \\
(9)\end{array}$ & $\begin{array}{c}45 \pm 18 \\
(7) \\
203 \pm 11 \\
(8)\end{array}$ & $\begin{array}{c}95 \pm 38 \\
(8) \\
277 \pm 23 \\
(10)\end{array}$ & $\begin{array}{c}61 \pm 17 \\
(7) \\
2058 \pm 413 \\
(7)\end{array}$ \\
\hline Brain ................. & $\begin{array}{l}13 \\
20\end{array}$ & $\begin{array}{c}327 \pm 75 \\
(7) \\
1132 \pm 106 \\
\text { (9) }\end{array}$ & $\begin{array}{c}115 \pm 25 \\
(7) \\
909^{ \pm} 53 \\
(8)\end{array}$ & $\begin{array}{c}157 \pm 48 \\
(7) \\
1413 \pm 155 \\
(10)\end{array}$ & $\begin{array}{c}186 \pm 50 \\
(7) \\
857 \pm 61 \\
(9)\end{array}$ \\
\hline
\end{tabular}


and brain were excised. The organs were homogenized in $0.12 \mathrm{M} \mathrm{KCl}$. The homogenates were used for determinations of MAO activity with a method using tryptamine-2${ }^{14} \mathrm{C}$-bisuccinate (New England Nuclear) as substrate (Wurtman and Axelrod, 1963). Duplicate determinations were performed for each sample. Blanks consisted of boiled homogenates.

Results are expressed in cpm of indoleacetic acid formed per $20 \mathrm{~min}$ and per $0.1 \mathrm{mg}$ of fresh tissue weight. Mean values are given with the standard error (SE). Statistical analyses were performed using Snedecor's F test.

Studies in vitro. - In order to determine if cardiac MAO activity was modified in vitro by thyroid hormones, normal males were killed at various times of development : from 18.5 days of fetal life to 20 days after birth, and adulthood (160-day old animals). MAO activity of cardiac homogenates was determined as described above, after the homogenates had been preincubated for $20 \mathrm{~min}$ at $37^{\circ} \mathrm{C}$ with thyroxin at a concentration of $1 \mu \mathrm{g} / \mathrm{ml}$. Controls were preincubated with the same volume of thyroxin solvent, i. e. $0.009 \mathrm{M} \mathrm{NaOH}$.

For each heart sample, control activity was taken as 100 p. 100 and the activity of the homogenate preincubated with thyroxin was calculated on this basis. Statistical analyses were performed with Student's t test.

\section{Results.}

Studies in vivo. - The enzymatic activities found $3 \mathrm{hrs}$ and 7 days after Pargyline injection are summarized in table 1 . The differences of activity between day 20 and day 13 are shown in figure 1 and reflect the de novo synthesis of MAO in that 7-day period.

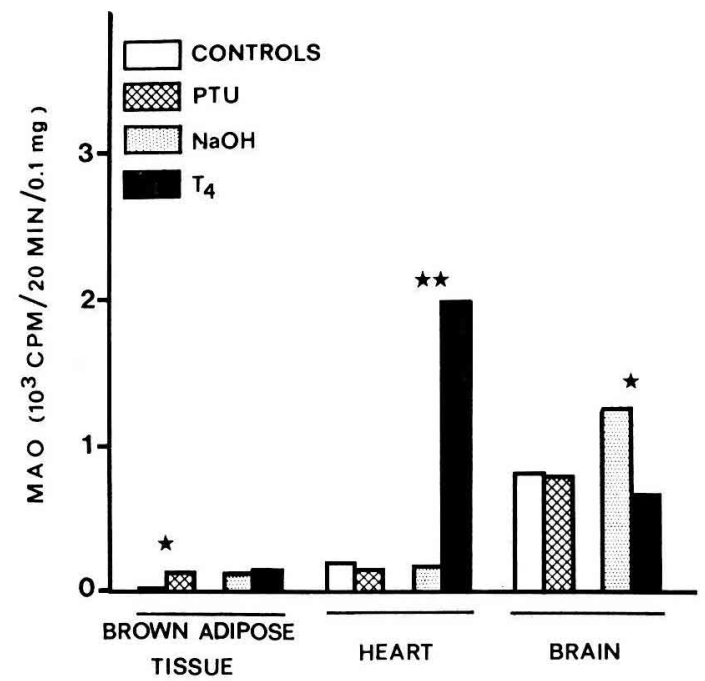

FIG. 1. - Recovery of MAO activity after irreversible inhibition by Pargyline : MAO activity at 20 days minus activity at 13 days (cpm/20 min/0.1 mg tissue). Statistical significance between PTU and Controls and between $\mathrm{T}_{4}$ and $\mathrm{NaOH}: * \mathrm{P}<0.05$; ** $P<0.01$. 
Hypothyroidism is followed by an increase of MAO synthesis in brown adipose tissue. Hyperthyroidism is followed by an increase in the heart $(+997$ p. 100) and a decrease in the brain.

Studies in vitro. - Figure 2 shows the effects of thyroxin on cardiac MAO activity in vitro. Under our experimental conditions thyroxin increases enzymatic activity only at the end of fetal life and just after birth, but has no effect at 18.5 days of fetal life and after 3 hrs of postnatal life.

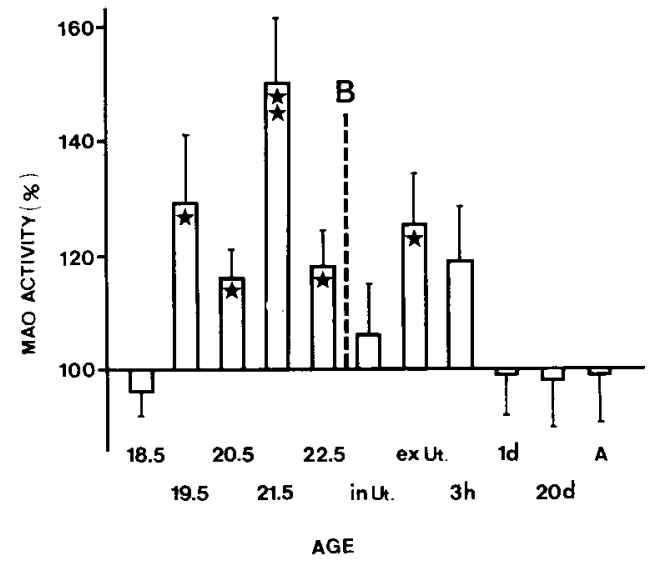

FIG. 2. - Effect of thyroxin on cardiac MAO activity in vitro. Results are expressed as percentages. Controls are taken as 100 p. 100 . Vertical bars represent the Standard Error. 18.5 to $22.5=$ days of fetal life ; in ut. = fetuses taken in the uterus of the mother after the first one was born ; ex ut. $=$ newborn animals taken less than half an hour after birth $; h=h r s$ after birth ; $d=$ days ; $A=$ adults.

Statistical significance from the controls : * $\mathrm{P}<0.05 ; * * \mathrm{P}<0.001$.

No. of animals : $18.5: 8 ; 19.5: 18 ; 20.5: 7 ; 21.5: 32 ; 22.5: 11 ;$ in ut: $10 ;$ ex uf: 17 ; $3 \mathrm{~h}: 15 ; 1 \mathrm{~d}: 14 ; 20 \mathrm{~d}: 7 ; \mathrm{A}: 8$.

\section{Discussion and conclusion.}

The rate of recovery of MAO activity after irreversible inhibition by Pargyline has been already used (Erwin and Deitrich, 1971 ; Planz et al., 1972a, b ; Goridis and Neff, 1973 ) to determine the rate of synthesis of MAO. It was found that activity increased as a function of time for at least 7 days after the administration of the inhibitor. The results shown in figure 1 are thus a reasonable measurement of the rate of synthesis of MAO or net gain between synthesis and degradation.

In the heart, hyperthyroidism results in an increase of the rate of synthesis of MAO. We have previously shown that MAO activity in the same organ increased in hyperthyroid animals at 15 or 20 days after birth (Gripois and Fernandez, 1976, 1977a). The same type of correlation may also be found for the brain. In the brown adipose tissue of 20-day old rats, MAO activity is increased during hypothyroidism and decreased during hyperthyroidism (unpublished results) ; the recovery of enzymatic activity after inhibition is more rapid in hypothyroid rats than in controls. 
In most of the present cases, there are comparable differences among the four groups of animals concerning enzymatic activity and the rate of synthesis of the enzyme. It is thus highly probable that the modifications of enzymatic activity observed previously are due to differences in the rate of synthesis of the enzyme. Goridis and Neff (1973) have previously shown that triiodothyronine increased both the activity of MAO and its rate or synthesis in rat salivary glands, while thyroidectomy had no effect on these parameters.

Our results on the effects of thyroxin on MAO in vitro show that cardiac MAO activity is directly sensitive to thyroid hormones during a very short period of development, i. e. at the end of fetal life. Similar results were found in the brain (unpublished data). In this case, the effects of thyroxin cannot be attributed to alterations of the synthesis rate of the enzyme, but only to differences in enzymatic activity. These findings agree with a previous observation (Tong and d'lorio, 1976) that mixing different subcellular fractions of rat heart resulted in neither inhibition nor activation of the mitochondrial and microsomal activities of control animals by the soluble fraction of hyperthyroid animals and vice versa, indicating the absence of an activator or an inhibitor of MAO activity in the adult. It was also found that, while rat brain MAO may be activated in vitro by thyroid hormones, the cardiac enzyme was insensitive to these hormones (Asaad and Clarke, 1975). It is of interest to note that MAO becomes sensitive to thyroxin one day after the fetal thyroid has begun secretion (Geloso, 1961). This effect could be mediated through fluidity variations of mitochondrial membranes which changes according to the thyroid state (Hulbert ef al., 1976) or through direct interaction between thyroxin and the active site of the enzyme. The reason for the disappearance of this sensitivity just after birth is still unknown, but the present results confirm a previous conclusion that thyroid control of MAO decreases with increasing age of the animals (Gripois and Fernandez, 1977b).

Comparing the two types of results, in vivo and in vitro, we may conclude that the differences in the development of MAO activity, in the hyper-and hypothyroid states in the newborn rat, are due to differences in the rate of synthesis of the enzyme. In this respect, the finding that thyroid hormones bind to nuclear receptors (Oppenheimer et al., 1972) makes it likely that thyroxin can regulate MAO synthesis. In the heart of the fetus, these differences may morever be aftributed to a direct effect of thyroxin on MAO activity.

Reçu en février 1978.

Accepté en mai 1978.

Acknowledgments. - This work was supported by DGRST grant 77-7-0659. The author is grateful to Abbott Laboratories for supplying Pargyline, and to Professor J. C. Gounelle for kindly extending the use of his laboratory facilities.

Résumé. Des résultats antérieurs ont mis en évidence des variations dans le développement de l'activité de la monoamine oxydase chez de jeunes rats hyper- et hypothyroïdiens. Le but du présent travail est de déterminer si ces modifications sont dues aux effets de la thyroxine sur l'activité enzymatique ou sur la synthèse de l'enzyme.

La vitesse de synthèse de la monoamine oxydase a été étudiée chez de jeunes rats hyperet hypothyroïdiens, en mesurant l'activité enzymatique 7 jours après inhibition irréversible par la Pargyline. L'hyperthyroïdisme détermine une augmentation du taux de synthèse 
de la monoamine oxydase dans le cour et une diminution dans le cerveau. Par contre, l'hypothyroïdisme provoque une augmentation de cette synthèse dans le tissu adipeux brun.

L'activité de la monoamine oxydase cardiaque est augmentée par la thyroxine in vitro dans les derniers jours de la vie fœetale; elle reste inchangée chez le nouveau-né et l'adulte. Ces résultats montrent que chez le jeune rat, le contrôle de l'activité de la monoamine oxydase par la thyroxine s'effectue surtout par des modifications du taux de synthèse de l'enzyme.

\section{References}

ASAAD M. M., CLARKE D. E., 1975. In vitro activation of brain monoamine oxidase activity by L-triiodothyronine. Pharmacologist, 17, 228.

CALLINGHAM B. A., LYLES G. A., 1974. An effect of thyroid hormones upon monoamine oxidase activity. Brit. J. Pharmacol., 51, 113P-114P.

ERWIN V. G., DEITRICH A., 1971. The labeling in vivo of monoamine oxidase by ${ }^{14} \mathrm{C}$-Pargyline : a tool for studying the synthesis of the enzyme. Mol. Pharmacol., 7, 219-228.

GELOSO J. P., 1961. Date de l'entrée en fonction de la thyroïde chez le foetus de rat. C. R. Soc. Biol., 155, 1239-1244.

GORIDIS C., NEFF N. H., 1973. Neuronal and hormonal influences on the turnover of monoamine oxidase in salivary gland. Biochem. Pharmacol., 22, 2501-2510.

GRIPOIS D., FERNANDEZ C., 1976. Influence des hormones thyroïdiennes sur l'activité de la monoamine oxydase chez le rat nouveau-né. C. R. Acad. Sci. Paris, sér. D , 283, 1225-1227.

GRIPOIS D., FERNANDEZ C., 1977a. Effects of thyroid hormones on the evolution of monoamine oxidase activity in the brain and heart of the developing rat. Enzyme, 22, 378-384.

GRIPOIS D., FERNANDEZ C., 1977b. Thyroxine- and propylthiouracil-induced changes in the activity of monoamine oxidase in the fetal rat. Mech. Age. Develop., 6, 407-412.

HULBERT A. J., AUGEE M. L., RAISON J. K., 1976. The influence of thyroid hormones on the structure and function of mitochondrial membranes. Biochim. biophys. Acto, 455, 597-601.

LYLES G. A., CALLINGHAM B. A., 1974. The effects of thyroid hormones on monoamine oxidase in the rat heart. J. Pharm. Pharmacol., 26, 921-930.

MOONAT L. B. S., ASAAD M. M., CLARKE D. E., 1975. L-thyroxine and monoamine oxidase activity in the kidney and some other organs of the rat. Res. Comm. Chem. Pathol. Pharmacol., 12, 765-780.

NOVICK W. J., 1961. The effect of age and thyroid hormones on the monoamine oxidase of rat heart. Endocrinology, 69, 55-59.

OKAMOTO H., 1971. Influence of L-thyroxine on kynurenine-3-hydroxylase, monoamine oxidase and rotenone-insensitive-NADH-cytochrome $\mathrm{C}$ reductase in mitochondrial outer membrane. Biochem. biophys. Res. Comm., 43, 827-833.

OPPENHEIMER J. H., KOERNER D., SCHWARTZ H. L., SURKES M. I., 1972. Specific nuclear triiodothyronine binding sites in rat liver and kidney. J. clin. Endocrinol. Metab., 35, 330-333.

PLANZ G., QUIRING K, PALM D., 19720. Rate of recovery of irreversibly inhibited monoamine oxidases : a measure of enzyme protein turnover. Naunyn- Schmied. Arch. Pharmakol., 273, 27-42.

PLANZ G., QUIRING K., PALM D., 1972b. Turnover rates of monoamine oxidases : recovery of the irreversibly inhibited enzyme activity and the influence of isoproterenol. Life Sci., 11, 147-160.

TONG J. H., D'IORIO A., 1976. Differential effects of L-thyroxine on cardiac and hepatic monoamine oxidase activity toward benzylamine and serotonin. Endocrinology, 98, 761-766.

UTLEY H. G., 1964. Effect of thyromimetic compounds on myocardial and hepatic monoamine oxidase activity in the rat. Endocrinology, 75, 975-977.

WURTMAN R. J., AXELROD J., 1963. A sensitive and specific assay for the estimation of monoamine oxidase. Biochem. Pharmacol., 12, 1439-1440. 